\title{
CULTIVATION OF Chlorella vulgaris IN MEDIUM SUPPLEMENTED WITH DESALINATION CONCENTRATE GROWN IN A PILOT-SCALE OPEN RACEWAY
}

\author{
Â. P. Matos ${ }^{1,3 *}$, W. B. Ferreira ${ }^{2}$, L. R. I. Morioka ${ }^{1}$, \\ E. H. S. Moecke ${ }^{1,4}$, K. B. França ${ }^{3}$ and E. S. Sant'Anna ${ }^{1}$ \\ ${ }^{1}$ Laboratory of Food Biotechnology, Department of Food Science and Technology, Federal University of Santa Catarina, Av. Admar \\ Gonzaga 1346, Itacorubi, 88034-001, Florianópolis - SC, Brazil. \\ 2 Department of Environmental Engineering, State University of Paraíba, Rua Baraúnas 351, 58429-500, Campina Grande - PB, Brazil. \\ ${ }^{3}$ Laboratory of Reference in Desalination, Department of Chemical Engineering, Federal University of Campina Grande, Av. Aprígio \\ Veloso, Bodocongó, 58109-970, Campina Grande - PB, Brazil. \\ ${ }^{4}$ Laboratory of Environmental Engineering, Southern University of Santa Catarina, Av. Pedra Branca, Unidade Pedra Branca, 88137-270, \\ Palhoça-SC, Brazil.
}

(Submitted: June 28, 2017 ; Revised: October 30, 2017 ; Accepted: December 10, 2017)

\begin{abstract}
In this study, we investigated the outdoor production of a microalga C. vulgaris cultured in two different media under autotrophic cultivation: Bold Basal Medium (BBM) as the control and BBM supplemented with desalination concentrate $(\mathrm{BBM}+\mathrm{DC})$ using open raceway ponds $\left(8 \mathrm{~m}^{2}\right)$. Data were collected on the growth, biomass productivity and biochemical composition. The culture developed in BBM + DC showed a biomass productivity of $6.8 \mathrm{~g} \mathrm{~m}^{-2} \mathrm{day}^{-1}$, while for the BBM control it was $8.5 \mathrm{~g} \mathrm{~m}^{-2} \mathrm{day}^{-1}$. Intracellular protein was the main algal component $(\sim 28.6 \%)$, followed by carbohydrate + fiber $(\sim 26.0 \%)$ and lipids $(\sim 5.0 \%)$. The predominant fatty acids were mainly $\alpha$-linolenic $(\sim 19.5 \%)$, palmitic $(\sim 16.5 \%)$ and linoleic $(\sim 10.0 \%)$ acids. This study demonstrates the feasibility of culturing $C$. vulgaris in an alternative medium based on DC in order to valorize the desalination wastewater through its application to algal mass production.

Keywords: Desalination wastewater; Algal cultivation; Autotrophic system; Biochemical composition; Protein.
\end{abstract}

\section{INTRODUCTION}

The northeast region of Brazil, which has a semiarid climate and frequent droughts, is a vast region $(982,563$ square kilometers) with brackish groundwater. To face the scarcity of good quality water in some parts of the semiarid region of Brazil, brackish groundwater has been desalinized to make it appropriate for use (Ministério do Meio Ambiente, 2004). Desalination through reverse osmosis is the most attractive solution for water supply (Sánchez et al., 2015). Equipment for the desalination of water based on reverse osmosis has been installed in the community of Uruçu, located in
São João do Cariri - Paraíba state. In general, the piped groundwater has a flow intake of around $2-3 \mathrm{~m}^{3} / \mathrm{h}$, operating with an average recovery rate of $90 \%$. As a result, a waste stream of brine with a high concentration of sodium, calcium and chlorides is produced.

Extensive research studies have been conducted using many types of wastewater for microalgae cultivation, particularly in raceway ponds. As examples, municipal wastewater has been used to grow many types of algae (Pittman et al., 2011), concentrate from anaerobic digestion for the cultivation of Scenedesmus sp. (Tran et al., 2014; Morales-Amaral et al., 2015), effluent from anaerobic digestion to grow Spirulina

\footnotetext{
* Corresponding author: E-mail address: angelosotam@gmail.com (AP Matos)
} 
sp. LEB-18 (Borges et al., 2013), pig wastewater for the cultivation of Spirulina (Arthrospira) (Olguín et al., 2003) and dairy wastewater to grow Chlorella zofingiensis (Huo et al., 2012). Our focus, however, is to produce algal biomass in a medium combined with desalination concentrate (DC), particularly aimed at developing a system which could be integrated with an inland desalination plant. The current model was designed in the community of Uruçu (Paraíba state, Brazil) as a possible site for algal production due to its favorable climate conditions (low seasonal variation and ample solar irradiance) and geography (local source of brackish groundwater and flat topography).

In an open raceway ponds system, two key factors determine the suitability of a microalga for biomass production: the areal productivity (the amount of biomass per unit area $\left(\mathrm{m}^{2}\right)$ per unit time (day)) (Lawton et al., 2015) and the biochemical composition (Batista et al., 2013; Tibbetts et al., 2015). The microalgae commonly cultivated in raceway ponds include Nannochloropsis sp., Chlorella sp., Tetraselmis sp., Arthrospira (Spirulina) platensis, Dunaliella salina, Scenedesmus sp. and Haematococcus pluvialis (Kumar et al., 2015; Varshney et al., 2015). Most biotechnological research on microalgae has been carried out using Chlorophyta (Varshney et al., 2015). The microalga $C$. vulgaris (Trebouxiophyceae) used in this study is a unicellular alga, 5 to $8 \mu \mathrm{m}$ in diameter (Graham et al., 2008). In addition, the genus Chlorella is widely cultured in open raceway ponds under different wastewater conditions (Pittman et al., 2011; Chu et al., 2015; Lu et al., 2015). Furthermore, the Chlorella freshwater microalgae have been targeted for biomass applications due to their high productivity, favorable biochemical composition, cosmopolitan distribution and competitive dominance over other algal species in open culture systems (Wu et al., 2007; Huo et al., 2012). C. vulgaris is also a potential source of lipids, which represent a promising pathway to obtain biofuels from microalgae (Halim et al., 2012; El-Sheekh et al., 2013; Skorupskaite et al., 2015).

The present study was carried out following a project designed to evaluate the performance of $C$. vulgaris produced in a medium containing DC. Herein, we describe the outdoor batch growth of $C$. vulgaris in open raceway ponds. The main aim of this research was to investigate the biomass productivity and biochemical composition (e.g., fiber, protein, lipids and fatty acids) of $C$. vulgaris cultivated in two different media: (1) Bold Basal Medium (BBM) as the control; and (2) BBM supplemented with desalination concentrate $(\mathrm{BBM}+\mathrm{DC})$ under the natural climatic conditions of the semiarid region of Brazil. As far as the authors are aware, this is the first description of combining desalination wastewater and algal cultivation in the Northeast region. The importance of this study lies not only in the scientific field, but also relates to the practical application of such a system, not only in the community of Uruçu (Paraíba state) but in the rest of the semiarid regions of Brazil.

\section{MATERIALS AND METHODS}

\section{Microalgal Species and Inoculum Preparation}

The freshwater microalga C. vulgaris was obtained from the Laboratory of Food Biotechnology at the Federal University of Santa Catarina. The alga was maintained in autoclaved BBM, which is suitable for freshwater algae (Nichols, 1973). The mineral salt medium composition, per liter of distilled water was: $0.075 \mathrm{gK}_{2} \mathrm{HPO}_{4}, 0.014 \mathrm{gKH}_{2} \mathrm{PO}_{4}, 0.075 \mathrm{gMgSO}_{4} .7 \mathrm{H}_{2} \mathrm{O}$, $0.09 \mathrm{~g} \mathrm{NaNO}_{3}, 0.025 \mathrm{~g} \mathrm{CaCl}_{2} .2 \mathrm{H}_{2} \mathrm{O}, 0.025 \mathrm{~g} \mathrm{NaCl}$, $0.05 \mathrm{~g}$ EDTA-Na $, 0.00498 \mathrm{~g} \mathrm{FeSO}_{4} .7 \mathrm{H}_{2} \mathrm{O}, 0.01142 \mathrm{~g}$ $\mathrm{H}_{3} \mathrm{BO}_{3}, 0.232 \mathrm{mg} \mathrm{MnCl} \mathrm{Mn}_{2} .4 \mathrm{H}_{2} \mathrm{O}, 1.41 \mathrm{mg} \mathrm{ZnSO} \mathrm{Zn}_{4} .7 \mathrm{H}_{2} \mathrm{O}$, $0.252 \mathrm{mg} \mathrm{CuSO}_{4} .5 \mathrm{H}_{2} \mathrm{O}, 0.192 \mathrm{mg} \mathrm{NaMoO} .5 \mathrm{H}_{2} \mathrm{O}$ and $0.080 \mathrm{mg} \mathrm{CoCl} \mathrm{Co}_{2} \cdot 6 \mathrm{H}_{2} \mathrm{O}$. A stock culture was grown at $26^{\circ} \mathrm{C}$ in a constant-temperature room under $75 \mu \mathrm{mol}$ photons $\mathrm{m}^{-2} \mathrm{~s}^{-1}$ provided by a combination of cool white (OSRAM Universal, Brazil) and day-light fluorescence lamps on a 12:12 h light/dark cycle. The cultures were first developed in 2.0 L Erlenmeyer flasks, and then scale-up to a 50-L capacity fiber photobioreactor in the Laboratory of Reference in Desalination (LABDES) at the Federal University of Campina Grande (UFCG), Paraíba State, Brazil.

\section{Desalination Concentrate}

Desalination concentrate was collected from an inland desalination plant, located in the community of Uruçu, São João do Cariri, Paraíba State, Brazil. The brackish groundwater was pumped through a small tubular (100-mm diameter) well (27-m depth) and fed to the desalination tank. The DC samples were obtained after passing the brackish water through three parallel reverse osmosis membranes (FILMTEC ${ }^{\mathrm{TM}}$ TW30 4040, Midland, USA) using desalination equipment. The chemical compositions of the groundwater (from the well) and DC (Table 1) were determined according to standard methods described by APHA (2005).

\section{Ponds, Culture Conditions and Growth Measurements}

Two above-ground concrete open raceway ponds (area of $8 \mathrm{~m}^{2}, 5.0-\mathrm{m}$ length, 1.6-m width, 0.5-m depth and total capacity of $4,000 \mathrm{~L} / 4 \mathrm{~m}^{3}$ for each pond) were employed in this study. The outdoor experiments were conducted in 2012 between mid-January and February (austral summer) at an experimental algal farm facility 
located in the community of Uruçu, São João do Cariri, Paraíba Sate, Brazil (07²3'27' S, 36 31'58”O) with an altitude of approximately $458 \mathrm{~m}$. According to the Koppen classification, the climate in the study region can be described as semiarid (BSh classification) with temperatures varying from $20^{\circ} \mathrm{C}$ to $35^{\circ} \mathrm{C}$ during the year.

In order to proceed with the experimental studies in the open raceway ponds, two different media were prepared: (1) BBM (control treatment); and (2) BBM supplemented with $25 \%$ of desalination concentrate $(\mathrm{BBM}+\mathrm{DC})$ (Figure 1). The ponds were inoculated with exponential-phase inoculum of $C$. vulgaris grown outdoors in fiber photobioreactors $(120 \mathrm{~L})$ placed under natural light illumination and temperature, with saturated air- $\mathrm{CO}_{2}$ (concentration of $0.03 \% \mathrm{CO}_{2}$ by volume with a flow rate of $1.5 \mathrm{~L} \mathrm{~min}^{-1}$ ) constantly injected into the photobioreactors.

Approximately $1500 \mathrm{~L}$ of fresh culture medium $(B B M)$ and $(B B M+D C)$ was supplied to the open raceway ponds. After 8 days of cultivation, $2000 \mathrm{~L}$ of fresh culture medium (BBM) and (BBM + DC) was further added to the two ponds, promoting the microalgal growth until the final working volume $(3500 \mathrm{~L})$ was reached. The open raceway ponds were
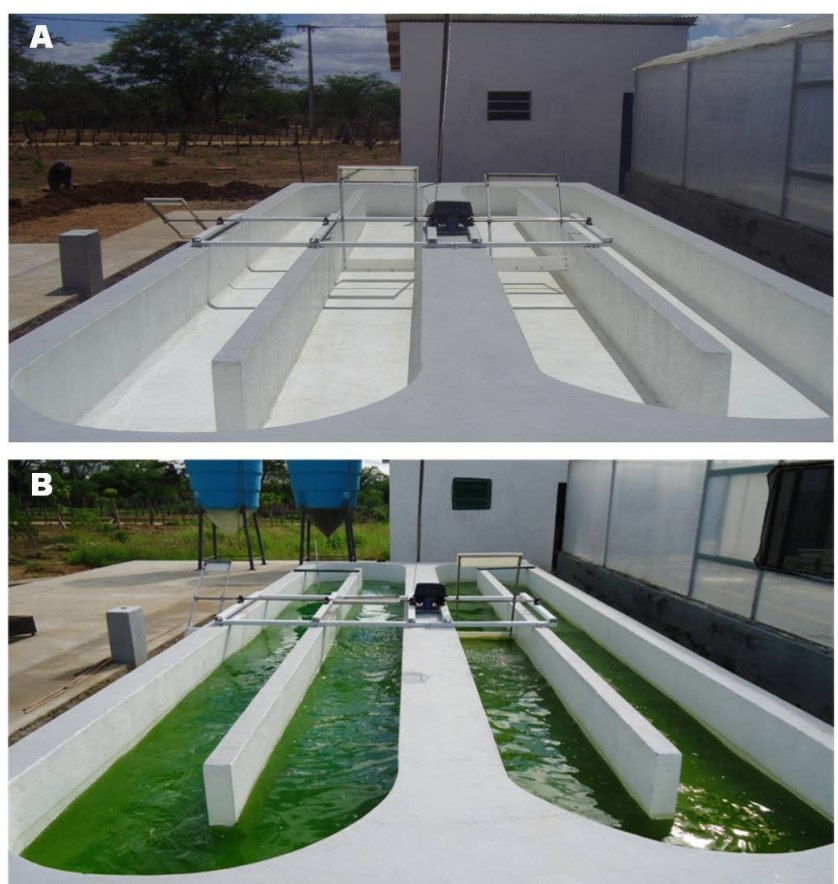

Figure 1. View of the open raceway ponds for microalgae cultivation at an experimental algal farm facility located in the community of Uruçu, São João do Cariri - Paraíba State, Brazil. A - Photograph of the ponds $(5.0-\mathrm{m}$ long, $1.6-\mathrm{m}$ width and $0.5-\mathrm{m}$ depth; totaling $8 \mathrm{~m}^{2}$ and total capacity of $4,000 \mathrm{~L} / 4 \mathrm{~m}^{3}$ each pond); $\mathrm{B}$ - Cultures of $C$. vulgaris in BBM (control, left) and BBM supplemented with DC (BBM + DC, right). operated in a batch mode (14 days) of cultivation, mixed using a paddle wheel programmed for 10min periods (i.e., turned on/off at regular intervals) $24 \mathrm{~h}$ a day, under the exact same conditions (nutrient replenishment, $\mathrm{pH}$, solar incidence, paddle wheel velocity, etc.). There was no external diffusion of carbon dioxide through the mechanical systems during the experimental cultivation. Evaporation losses were at the rate of 1 to $2 \mathrm{~cm} /$ day and were replenished with water every morning. Fresh water was used to replace evaporative losses. When the microalgal culture reached a stationary growth phase after 14 days, all of the culture volume from the open raceway pond was pumped into a 4000-L open-top conical tank. Based on previous laboratory results, as reported by Morioka et al. (2014) for Chlorella flocculation, the $\mathrm{pH}$ of the culture was elevated to $10.5-12.0$ by adding $(\mathrm{NaOH})+$ 0.5-1.0 $\mathrm{g} \mathrm{L}^{-1}$ of flocculant $\mathrm{CaCl}_{2}$. The suspension was manually mixed with a tool (shovel) for 10-15 min and then left to stand overnight (12 h). After the partial sedimentation, the biomass slurry was harvested by continuous centrifugation (Motortronics centrifuge, USA) at $3600 \mathrm{rpm}$ for approximately $3 \mathrm{~h}$. The microalgal pellet was transferred to a dish and dried at $60^{\circ} \mathrm{C}$. The dried microalgal biomass samples were transported to the Laboratory of Food Biotechnology (BIOTEC) at the Federal University of Santa Catarina (UFSC) for further analysis to determine the biochemical composition.

Water temperature, $\mathrm{pH}$, dissolved oxygen (DO) and conductivity were measured on-line and recorded continuously every day, using an HI 9828 Series HANNA Multiparameter probe (HANNA, Romania). The Illuminance was obtained using a digital lux meter LD-500 series (ICEL, Brazil).

Growth parameters were measured every day (for cell density and biomass productivity), using the methods described by Lourenço (2006). Cell counting was carried out using a hemocytometer and a compound microscope (Olympus, Germany). For the biomass production, a sample of the microalgae in the growth medium ( $10 \mathrm{~mL}$ suspension) was filtered through glass microfiber GF/C filter paper (Whatmann, New York, USA) and washed twice with distilled water. The paper with attached cells was dried at $105^{\circ} \mathrm{C}$ for $1 \mathrm{~h}$, and then kept over a desiccant in a vacuum desiccator overnight.

The chlorophyll $a$ concentration was estimated as described by Ritchie (2006) as an indicator of algal biomass growth. A volume of $25 \mathrm{~mL}$ of each sample was filtered through the $0.40 \mu \mathrm{m}$ glass microfiber $\mathrm{GF} / \mathrm{C}$ filter paper (Whatman, USA). Chlorophyll $a$ was extracted from filters with $90 \%$ acetone $\left(\operatorname{Vetec}^{\circledR}\right)$. Absorbance of the extract was measured at $660 \mathrm{~nm}$ (chlorophyll $a$ ) and $750 \mathrm{~nm}$ (turbidity) with a Hach 
spectrophotometer (Loveland, CO, USA). Chlorophyll $a$ concentration $\left(\mu \mathrm{g} \mathrm{mL}^{-1}\right)$ was calculated from Eq. 1 .

$$
C=\left(A_{660}-A_{750}\right) * V / V_{s} * 11.3 / L / 1000
$$

where $C$ is the chlorophyll $a$ concentration $\left(\mu \mathrm{g} \mathrm{mL}^{-1}\right), V$ is the volume of solvent $(\mathrm{mL}), V_{s}$ is the volume of sample $(\mathrm{L})$, and $L$ is the light path $(\mathrm{cm}) . A$ is the absorbance and 11.3 is the specific extinction coefficient for acetone.

Biomass productivity calculation $\left(\mathrm{g} \mathrm{m}^{-2}\right.$ day $\left.^{-1}\right)$ was determined according to Bhowmick et al. (2014) Eq. (2):

$A P=\frac{(F C D-I C D) \times W V}{B R T \times C A O}$

where AP is the aerial productivity (for carpet area occupied), FCD is the final culture density, ICD is the initial culture density, WV is the working volume, $\mathrm{BRT}$ is the batch run time, and CAO is the carpet area occupied.

\section{Analytical Procedures}

Moisture - Moisture was determined by drying the sample in an oven at $105^{\circ} \mathrm{C}$ for 3-4 h (until constant weight) (AOAC, 2005).

Ash content - Total ash content was determined by heating the samples to $550^{\circ} \mathrm{C}$ and holding this temperature for $5 \mathrm{~h}$ in a carbolite muffle furnace (IAL, 2005).

Fiber content - Total dietary fiber (TDF) content was determined with a total dietary fiber analysis kit (Megazyme International Ireland Ltd, Wicklow, Ireland), which includes enzymatic hydrolysis with $\alpha$-amylase, protease and amyloglucosidade and is approved by the AACC (Method 32-05-01) and the AOAC (Official Method 985.29). Duplicate samples (approximately $1 \mathrm{~g}$ ) were suspended in 50 $\mathrm{mL}$ phosphate buffer and submitted to enzymatic hydrolysis by incubating with $50 \mu \mathrm{L}$ of $\alpha$-amylase at $60^{\circ} \mathrm{C}$ for $30 \mathrm{~min}$. The $\mathrm{pH}$ was adjusted to $7.5,100 \mu \mathrm{L}$ of protease was added and the samples were incubated at $60^{\circ} \mathrm{C}$ for $30 \mathrm{~min}$. In the next step, the $\mathrm{pH}$ was adjusted to $4.5,200 \mu \mathrm{L}$ of amyloglucosidade was added and the samples were incubated at $60^{\circ} \mathrm{C}$ for $30 \mathrm{~min}$. Lastly, the fiber was precipitated with $95 \%$ ethanol at $60^{\circ} \mathrm{C}$, filtered through fritted glass crucibles with a Celite filter and the residue in the crucible was dried in an oven at $105^{\circ} \mathrm{C}$, cooled in a desiccator and weighed.

Protein content - Total nitrogen was determined by the Kjeldahl method after acid digestion, ammonium addition, steam distillation and titration with $0.1 \mathrm{~N}$ $\mathrm{HCl}$ (AOAC, 2005). Protein content was calculated using a nitrogen-to-protein conversion factor of $\mathrm{N} \mathrm{x}$ 4.78 (Lourenço et al., 2004).

Lipid content - Intracellular lipids were extracted by the Soxhlet method with petroleum ether for 6 $\mathrm{h}$, after acid digestion with $4 \mathrm{~N} \mathrm{HCl}$, followed by concentration in a rotary evaporator. The samples were then dried in an oven and weighed (AOAC, 2005).

Total carbohydrates - Total carbohydrate contents were calculated as follows: $(100 \%-$ (moisture + ash + protein + fiber + lipid) (ANVISA, 2003).

Fatty acid analysis - The fatty acids composition was determined after converting the fatty acids to their corresponding fatty acid methyl esters (FAME) (IAL, 2005), by gas chromatography using a GC2014 (Shimadzu, Kyoto, Japan), equipped with a split-injection port, flame-ionization detector and $105 \mathrm{~m}$-long Restek capillary column (ID $=0.25 \mathrm{~mm}$ ) coated with $0.25 \mu \mathrm{m}$ of $10 \%$ cyanopropylphenyl and $90 \%$ biscyanopropylsiloxane. The injector and detector temperatures were both set at $260^{\circ} \mathrm{C}$. The oven temperature was initially set at $140^{\circ} \mathrm{C}$ for $5 \mathrm{~min}$, then increased at $2.5^{\circ} \mathrm{C} \mathrm{min}^{-1}$ to $260^{\circ} \mathrm{C}$ which was held for $30 \mathrm{~min}$. The injection volume was $1 \mu \mathrm{L}$, and the split ratio was 10:1. Nitrogen was used as the carrier gas (flow rate $2.2 \mathrm{~mL} \mathrm{~min}^{-1}$ ) at a constant pressure of $130.3 \mathrm{kPa}$. Fatty acid methyl esters were identified by comparison with the retention time of individual standards (Sigma, St. Louis, USA). The proportions of the individual acids were calculated from the ratio of their peak area to the total area of all observed acids and expressed as a mass percentage.

\section{RESULTS AND DISCUSSION}

\section{Preliminary Studies of the Optimal DC Concentration for $C$. vulgaris Cultivation}

Thirteen microelements were detected in the groundwater and DC (Table 1). The DC is rich in $\mathrm{Cl}^{-}$, $\mathrm{Na}^{+}$and $\mathrm{Ca}^{2+}$. In addition, other nutrients $(\mathrm{N}$ and $\mathrm{P}$ ) and trace elements necessary for microalgae growth, including $\mathrm{K}^{+}, \mathrm{Mg}^{2+}$ and $\mathrm{Fe}^{3+}$, were detected in the DC. To assess the applicability of DC as a culture medium for $C$. vulgaris cultivation, the DC was mixed with BBM in different percentages $(25 \%, 35 \%, 45 \%$ and $55 \%$ DC). Our previous experimental results obtained in the laboratory (Matos et al., 2015) showed that C. vulgaris was able to grow in media with all of the DC percentages studied; however, the biomass concentration and biochemical composition were significantly affected by the cultivation conditions. For example, at high DC concentrations (i.e., 45-55\% DC), the biomass concentration was $\sim 130 \mathrm{mg} \mathrm{L}^{-1}$ and the protein and lipid contents were in the ranges of 20.0 and $\sim 3.0 \%$, respectively, while upon growing the 
Table 1. Compositions of groundwater and desalination concentrate (DC) from the community of Uruçu, Paraíba State, Brazil.

\begin{tabular}{|c|c|c|}
\hline Parameters & Groundwater & DC \\
\hline $\mathrm{pH}$ & $7.3 \pm 0.5$ & $8.1 \pm 0.4$ \\
\hline Electrical conductivity $\left(\mathrm{EC}, m \mathrm{~S} \mathrm{~cm}^{-1}\right)$ & $3.0 \pm 0.8$ & $5.6 \pm 0.5$ \\
\hline Langelier Saturation Index (LSI) & 0.08 & 1.35 \\
\hline Total Dissolved Solids (TDS (mg L $\left.{ }^{-1}\right)$ & $1823.8 \pm 94$ & $3410.0 \pm 126$ \\
\hline $\mathrm{Cl}\left(\mathrm{mg} \mathrm{L}^{-1}\right)$ & $720.7 \pm 35$ & $1418.2 \pm 96$ \\
\hline $\mathrm{Na}\left(\mathrm{mg} \mathrm{L}^{-1}\right)$ & $464.0 \pm 66$ & $723.8 \pm 98$ \\
\hline $\mathrm{CaCO}_{3}\left(\mathrm{mg} \mathrm{L}^{-1}\right)$ & $506.5 \pm 97$ & $1080.0 \pm 125$ \\
\hline $\mathrm{Ca}\left(\mathrm{mg} \mathrm{L}^{-1}\right)$ & $74.0 \pm 10$ & $145.0 \pm 23$ \\
\hline $\operatorname{Mg}\left(\mathrm{mg} \mathrm{L}^{-1}\right)$ & $77.2 \pm 21$ & $172.2 \pm 14$ \\
\hline $\mathrm{SiO}_{2}\left(\mathrm{mg} \mathrm{L}^{-1}\right)$ & $48.2 \pm 11$ & $82.4 \pm 24$ \\
\hline $\mathrm{SO}_{4}^{2-}\left(\mathrm{mg} \mathrm{L}^{-1}\right)$ & $15.6 \pm 0.6$ & $102.1 \pm 12$ \\
\hline $\mathrm{K}\left(\mathrm{mg} \mathrm{L}^{-1}\right)$ & $7.0 \pm 2$ & $15.0 \pm 5$ \\
\hline $\mathrm{NO}_{3}^{-}-\mathrm{N}\left(\mathrm{mg} \mathrm{L}^{-1}\right)$ & $8.2 \pm 0.1$ & $15.4 \pm 0.1$ \\
\hline $\mathrm{NH}_{4}^{+}\left(\mathrm{mg} \mathrm{L}^{-1}\right)$ & $0.59 \pm 0.3$ & $1.35 \pm 0.8$ \\
\hline $\mathrm{PO}_{4}^{3-}-\mathrm{P}\left(\mathrm{mg} \mathrm{L}^{-1}\right)$ & $0.20 \pm 0.1$ & $0.80 \pm 0.3$ \\
\hline $\mathrm{Fe}\left(\mathrm{mg} \mathrm{L}^{-1}\right)$ & $0.05 \pm 0.1$ & $0.08 \pm 0.1$ \\
\hline
\end{tabular}

microalgae at $25-30 \% \mathrm{DC}$ the corresponding values were $600 \mathrm{mg} \mathrm{L}^{-1}, 48.5 \%$ and $12.5 \%$ (Figure 2). This indicates that $C$. vulgaris undergoes considerable growth inhibition at DC concentrations of $45-55 \%$ while it grows relatively well at DC concentrations of $25-30 \%$. According to Kumar et al. (2015), the salt concentration influences algae via effects on osmotic stress, salt stress, and cellular ionic ratios. As the ionic concentration of DC is too high for the cultivation of C. vulgaris, algae have low capability to tolerate a broader range of DC-salinities with a satisfactory growth. Under this assumption, we supplemented the BBM with $25 \%$ DC for $C$. vulgaris cultivation in outdoor experiments.

The most notable differences between BBM and $\mathrm{DC}$ are related to the $\mathrm{NaCl}$ content and electrical conductivity (EC). DC has a $\mathrm{NaCl}$ content of around $2412 \mathrm{mg} \mathrm{L}^{-1}$ and $\mathrm{EC}$ of $5.6 \mathrm{mS} \mathrm{cm} \mathrm{s}^{-1}$, while the corresponding values for BBM are $25 \mathrm{mg} \mathrm{L}^{-1}$ and 1.1 $m \mathrm{~S} \mathrm{~cm}{ }^{-1}$, respectively. Regarding the concentrations of the major nutrients that are required for microalgae growth ( $\mathrm{N}$ and $\mathrm{P}$ ) there are also differences. BBM

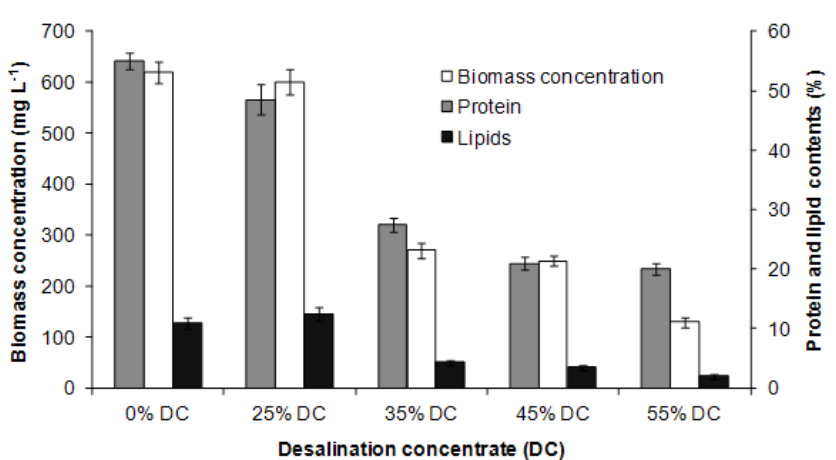

Figure 2. Effect of different concentrations of desalination concentrate (DC) on protein, lipid and biomass concentration of C. vulgaris under laboratory conditions. contains $\mathrm{N}$ in the form of nitrate, whereas in the $\mathrm{DC}$, besides nitrate, $\mathrm{N}$ is also present as $\mathrm{NH}_{4}^{+}$. Concerning the total $\mathrm{P}, \mathrm{BBM}$ contains $89 \mathrm{mg} \mathrm{PO}_{4}^{3-} \mathrm{L}^{-1}$ while the $\mathrm{DC}$ content is $0.80 \mathrm{mg} \mathrm{PO}_{4}^{3-} \mathrm{L}^{-1}$. In addition, $\mathrm{BBM}$ presents a N/P ratio of 2:1 and for $\mathrm{BBM}+\mathrm{DC}$ this ratio is 5:1. Park et al. (2011) have reported that the N/P ratio in wastewater can range from $4: 1$ to almost 40:1. Overall, the main difference between BBM and DC is that the latter contains high levels of mineral salts. In addition, a small quantity of ammonia $\left(1.35 \mathrm{mg} \mathrm{L}^{-1}\right)$ was detected in the DC along with sulfate $(102.0$ $m g \mathrm{~L}^{-1}$ ), compounds which can be toxic to aquatic life (Greenlee et al., 2009). For this reason, C. vulgaris has a limit of tolerance, which is a DC concentration of around $25-30 \%$ in the culture medium. It is also important to note that chemical pre-treatment and cleaning is a necessity in most desalination plants, which typically includes treatment with chemicals to avoid biofouling, scaling, foaming and corrosion in desalination plants, which may have adverse effects on aquatic organisms (Lattemann and Hopner, 2008; Melián-Martel et al., 2011).

\section{Water Quality, Algal Growth and Biomass Productivity}

Over the course of the outdoor experiment (14 days of cultivation), the water quality was recorded continuously on-line every day (Table 2). During the experiments, the average water temperature was around $33.1^{\circ} \mathrm{C}$ at mid-day and $\sim 23.0^{\circ} \mathrm{C}$ at night. Maximum dissolved oxygen (DO) values during the cultivation period were between 10.1 and $12.5 \mathrm{mg} \mathrm{mL}^{-1}$, with no significant difference between the two pond cultures. The initial and final $\mathrm{pH}$ values of the cultures were 8.10 and 9.40 , respectively. Illuminance ranged from 1,000 lux (during sunrise and sunset) to 80,000 lux (at mid-day). The values obtained for the variables 
electrical conductivity, alkalinity, total suspended solids (TSS) and turbidity dynamics for the two ponds were statistically different. For the outdoor pond containing $\mathrm{BBM}+\mathrm{DC}$, higher electrical conductivity $\left(2.2 \mathrm{mS} \mathrm{cm}^{-1}\right)$ and alkalinity $\left(538 \mathrm{mg} \mathrm{CaCO}_{3} \mathrm{~L}^{-1}\right)$ were observed compared with the BBM control $(1.1 \mathrm{mS}$ $\mathrm{cm}^{-1}$ and $200 \mathrm{mg} \mathrm{CaCO}_{3} \mathrm{~L}^{-1}$, respectively). In addition, TSS and turbidity were also higher in the BBM + DC culture. There were no significant differences in the chlorophyll $a$ concentrations for the ponds, with an average of around $350 \mathrm{mg} \mathrm{L}^{-1}$. Concerning the ammonium composition, the $\mathrm{NH}_{4}-\mathrm{N}$ content for BBM + DC (1.10 $\left.\mathrm{mg} \mathrm{L}^{-1}\right)$ was 4.5 times higher than that for the BBM control $\left(0.25 \mathrm{mg} \mathrm{L}^{-1}\right)$ (Table 2).

Initial results for the growth of $C$. vulgaris were similar in the two ponds containing the BBM control and $\mathrm{BBM}+\mathrm{DC}$ (Table 3). Based on the maximum cell density (MCD), C. vulgaris cells were denser in the BBM control $\left(1.2 \times 10^{6} \mathrm{cel} . \mathrm{mL}^{-1}\right)$ than in BBM $+\mathrm{DC}\left(8.9 \times 10^{5}\right.$ cel. $\left.\mathrm{mL}^{-1}\right)$ (Figure 3), while the average specific growth rate was $\sim 0.25 \mathrm{day}^{-1}$. The cultures grown in BBM control showed a biomass concentration of around $275 \mathrm{mg} \mathrm{L}^{-1}$, while for BBM + DC the result was $220 \mathrm{mg} \mathrm{L}^{-1}$. Actually, the outdoor cultivation of $C$. vulgaris resulted in an average biomass concentration of $250 \mathrm{mg} \mathrm{L}^{-1}$ and the data reported herein for the biomass concentration of the outdoor culture are comparable with results obtained by Cuello et al. (2015), which ranged from 263 to 403 mg $\mathrm{L}^{-1}$ using Tetraselmis suecica (Chlorophyta) in open raceway ponds.

The values for the biomass productivity of $C$. vulgaris obtained in the outdoor cultures, i.e., 8.5 $\mathrm{g} \mathrm{m}^{-2}$ day $^{-1}$ using BBM medium and $6.8 \mathrm{~g} \mathrm{~m}^{-2}$ day $^{-1}$ using $\mathrm{BBM}+\mathrm{DC}$, are close to those previously reported for this type of Chlorophyta species cultured

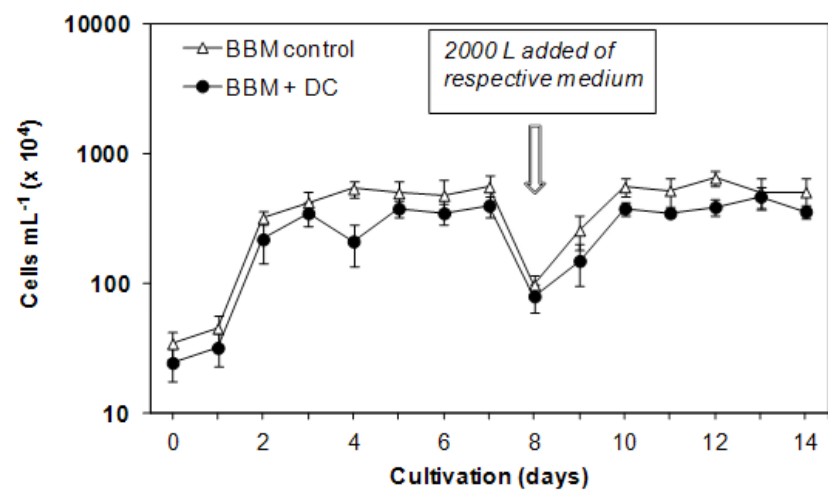

Figure 3. Growth curve of $C$. vulgaris cultivated in open raceway ponds with working volume of 3,500 L during 14 days; $(\Delta)$ Control treatment $(\mathrm{BBM})$ and $(\bullet)$ BBM supplemented with DC $(B B M+D C)$.

in raceway ponds, for example, $8.1 \mathrm{~g} \mathrm{~m}^{-2}$ day $^{-1}$ for Chlorella variabilis (Bhowmick et al., 2014) and $7.2 \mathrm{~g} \mathrm{~m}^{-2}$ day $^{-1}$ for Tetraselmis sp. MUR 233 (Raes et al., 2014). Using wastewater in raceways ponds, the biomass productivity reported generally ranges from 10 to $20 \mathrm{~g} \mathrm{~m}^{-2}$ day $^{-1}$ (e.g., Park et al., 2011). In one case, a biomass productivity of up to $24 \mathrm{~g} \mathrm{~m}^{-2}$ day $^{-1}$ was reported for Scenedesmus sp. using 30\% concentrate from anaerobic digestion as the nutrient source (Morales-Amaral et al., 2015). In contrast, a biomass productivity of $5.0 \mathrm{~g} \mathrm{~m}^{-2}$ day $^{-1}$ for Nannochloropsis gaditana using the same concentrate at $30 \%$ in the culture medium was reported by Ledda et al. (2015). More specifically biomass productivities in raceway ponds across the globe are well illustrated in Table 4.

\section{Analysis of the Biochemical Composition of $C$. vulgaris}

The biochemical compositions of C. vulgaris cultivated in the two proposed media (BBM and

Table 2. Median \pm standard deviation of water quality variables in the open raceway ponds with respectively culture medium - BBM (control) and BBM supplemented with DC (BBM + DC) - measured during 14 days of operation.

\begin{tabular}{ccc}
\hline Water quality variable & BBM & BBM + DC \\
\hline Temperature $\left.{ }^{\circ} \mathrm{C}\right)$ & $22.0-32.3^{\mathrm{a}}$ & $23.0-33.1^{\mathrm{a}}$ \\
$\mathrm{DO}\left(\mathrm{mg} \mathrm{L}^{-1}\right)$ & $12.50 \pm 1.0^{\mathrm{a}}$ & $10.15 \pm 0.5^{\mathrm{a}}$ \\
$\mathrm{pH}$ & $8.10-9.20^{\mathrm{a}}$ & $8.12-9.60^{\mathrm{a}}$ \\
$\mathrm{EC}\left(\mathrm{mS} \mathrm{cm}^{-1}\right)$ & $1.1 \pm 0.1^{\mathrm{a}}$ & $2.2 \pm 0.3^{\mathrm{b}}$ \\
Alkalinity $\left(\mathrm{mg} \mathrm{CaCO}_{3} \mathrm{~L}^{-1}\right)$ & $200.5 \pm 24^{\mathrm{a}}$ & $538.6 \pm 45^{\mathrm{b}}$ \\
Turbidity $\left(\mathrm{NTU}^{\mathrm{a}}\right)$ & $0.2 \pm 0.1^{\mathrm{a}}$ & $0.7 \pm 0.2^{\mathrm{a}}$ \\
TSS $\left(\mathrm{mg} \mathrm{L}^{-1}\right)$ & $57.5 \pm 5.2^{\mathrm{a}}$ & $100.5 \pm 3.3^{\mathrm{b}}$ \\
Chlorophyll $a\left(\mu \mathrm{g} \mathrm{mL} \mathrm{m}^{-1}\right)$ & $300 \pm 20^{\mathrm{a}}$ & $400 \pm 25^{\mathrm{a}}$ \\
$\mathrm{NH}_{4}-\mathrm{N}\left(\mathrm{mg} \mathrm{L}^{-1}\right)$ & $0.25 \pm 0.10^{\mathrm{a}}$ & $1.10 \pm 0.15^{\mathrm{b}}$ \\
\hline
\end{tabular}

TSS $=$ Total Suspended Solids. Different letters in the same row correspond to significant differences $(p<0.05)$ by Tukey test.

Table 3. Maximum cell density, the growth rate and biomass concentration of $C$. vulgaris cultured in open raceway ponds in control treatment (BBM) and BBM supplemented with DC (BBM + DC).

\begin{tabular}{ccc}
\hline Treatment & BBM & BBM + DC \\
\hline MCD $\left(\right.$ cel. $\left.\mathrm{mL}^{-1} \times 10^{4}\right)$ & $121 \pm 10^{\mathrm{a}}$ & $89 \pm 12^{\mathrm{a}}$ \\
Specific growth rate $\mu\left(\right.$ day $\left.^{-1}\right)$ & $0.26 \pm 0.05^{\mathrm{a}}$ & $0.25 \pm 0.05^{\mathrm{a}}$ \\
Biomass conc. $\left(\mathrm{mg} \mathrm{L}^{-1}\right)$ & $275 \pm 20^{\mathrm{a}}$ & $220 \pm 12^{\mathrm{a}}$ \\
\hline
\end{tabular}

$\mathrm{MCD}=$ maximum cellular density; Values shown are averages of three \pm the range. 
Table 4. Comparison of biomass productivities $\left(\mathrm{g} \mathrm{m}^{-2} \mathrm{day}^{-1}\right)$ in open raceway ponds between this study and literature values.

\begin{tabular}{|c|c|c|c|c|c|c|c|c|c|}
\hline Month & $\begin{array}{l}\text { Productivity } \\
\left(\mathrm{g} \mathrm{m}^{-2} \text { day }^{-1}\right)\end{array}$ & $\begin{array}{c}A^{*} \\
\left(\mathbf{m}^{2}\right)\end{array}$ & $\begin{array}{l}D^{* *} \\
(\mathrm{~m})\end{array}$ & $\begin{array}{l}V^{* * *} \\
\left(\mathrm{~m} \mathrm{~s}^{-1}\right)\end{array}$ & Duration & Species & Location & $\begin{array}{l}\text { Temp } \\
\left({ }^{\circ} \mathrm{C}\right)\end{array}$ & Reference \\
\hline Summer & 8.56 & 8 & 0.3 & 0.25 & Batch 14 days & Chlorella vulgaris & Brazil & $22-33$ & This work* \\
\hline Summer & 6.87 & 8 & 0.3 & 0.25 & Batch 14 days & Chlorella vulgaris & Brazil & $22-33$ & This work** \\
\hline Summer & 8.10 & 1.5 & 0.1 & 0.30 & Batch 15 days & Chlorella variabilis & India & 36 & Bhowmich et al. (2014) \\
\hline Summer & 26.3 & 25 & 0.2 & 0.20 & Semi continuous & Tetraselmis sp. MUR 233 & Australia & $10-28$ & Sing et al. (2014) \\
\hline Autumn & 7.2 & 1 & 0.2 & 0.22 & Semi continuous & Tetraselmis sp. MUR 233 & Australia & $12-22$ & Raes et al. (2014) \\
\hline Summer & 14.0 & 0.08 & 0.05 & $17 \mathrm{rpm}$ & Batch 19 days & Spirulina sp. LEB-18 & Brazil & $26-44$ & Borges et al. (2013) \\
\hline Summer & 10.6 & 25 & 0.15 & 0.23 & Semi continuous 55 days & Spirulina (Arthrospira) & South Africa & $20-35$ & Grobbellar (2009) \\
\hline Summer & 28.0 & 20 & & $12 \mathrm{rpm}$ & Semi continuous 24 days & Microcystis aeruginosa & Malaysia & $29-34$ & Ashokkumar et al. (2014) \\
\hline Spring & $6.0-7.9$ & 1192 & 0.26 & & Semi continuous & Nannochloropsis oculata & China & $12-26$ & Cheng et al. (2015) \\
\hline- & $9.0-13.0$ & 100 & 0.15 & & Semi continuous & Haematococcus pluvialis & United States & $16-34$ & Olaizola $(2000)$ \\
\hline Summer & 6.62 & 30.37 & 0.07 & 0.25 & Semi continuous & Scenedesmus acutus & United States & $12-38$ & Eustance et al. (2016) \\
\hline Spring & 24.0 & 32 & 0.12 & 0.20 & Semi continuous & Scenedesmus sp. & Spain & - & Morales-Amaral et al. (2015) \\
\hline Annually & $4.4-11.5$ & 14,000 & 0.35 & 0.20 & Semi continuous & Consortium algal/bacterial & New Zealand & $13-15$ & Craggs et al. (2012) \\
\hline
\end{tabular}

$\mathrm{BBM}+\mathrm{DC}$ ) in the outdoor experiment are shown in Table 5. The dried microalgal biomass presented intermediate moisture content (15.2-18.8\%). The ash content observed in the microalgal biomass cultured in $\mathrm{BBM}+\mathrm{DC}(32.8 \%)$ was higher than in the BBM control (14.5\%), the values being statistically different $(P<0.05)$, which is due to extra precipitated salts, including calcium carbonate, sodium and chlorides that are trapped in the DC-based medium. In addition, these extra salts may interfere in the extraction step for analysis of the proximate composition of the algal biomass (Moheimani et al., 2015).

The organic constituents (e.g., protein, carbohydrate + fiber and lipids) were the major components of the algal biomass studied and differences between the two ponds were observed, with protein being the most abundant component (average 28.6\%), followed by carbohydrate + fiber (average 26.0\%), and lipid content (average 4.7\%). The protein contents of the algal biomass samples were found to be significantly different $(P<0.05)$. The microalgae cultured in the BBM control showed a protein content of $37.2 \%$, almost 2-fold higher than the value for the BBM + DC (20.0\%). The reduced protein content in $C$. vulgaris cultured in $\mathrm{BBM}+\mathrm{DC}$ is most likely due to a redirection of available energy towards processes such as osmoregulation rather than towards the synthesis of proteins (Lawton et al., 2015; Matos et al., 2017).

With regard to the intracellular lipids, the total lipids varied from $5.8 \%$ (BBM control) to $3.7 \%$

Table 5. Chemical composition of $C$. vulgaris cultivated in open raceway ponds.

\begin{tabular}{ccc}
\hline Composition (\%) & BBM & BBM + DC \\
\hline Ash & $14.5 \pm 2.5^{\mathrm{a}}$ & $32.8 \pm 3.0^{\mathrm{b}}$ \\
Moisture & $15.2 \pm 0.9^{\mathrm{a}}$ & $18.8 \pm 1.4^{\mathrm{a}}$ \\
Protein & $37.2 \pm 2.7^{\mathrm{a}}$ & $20.0 \pm 2.1^{\mathrm{b}}$ \\
Fiber & $7.0 \pm 0.5^{\mathrm{a}}$ & $7.1 \pm 0.6^{\mathrm{a}}$ \\
Carbohydrate & $20.3 \pm 1.1^{\mathrm{a}}$ & $19.6 \pm 1.2^{\mathrm{a}}$ \\
Lipids & $5.8 \pm 0.6^{\mathrm{a}}$ & $3.7 \pm 0.5^{\mathrm{a}}$ \\
\hline
\end{tabular}

Values shown are averages of three \pm the range. Different letters in the same row correspond to significant differences $(p<0.05)$.
$(\mathrm{BBM}+\mathrm{DC})$ (Table 5). Actually, it is expected that $C$. vulgaris cultivated in outdoor conditions would show a lipid content of more than $15-20 \%$, while in this case the lipid content was low $(<4.0 \%)$, and unsustainable for biodiesel production. It has been noted that environmental factors/conditions such as diurnal, climatic and seasonal variations in temperature, humidity and light impart a profound effect on the biomass in outdoor microalgal cultivation (Varshney et al., 2015). In this regard, the harsh environmental conditions imposed in the present outdoor experiment [i.e., high temperatures $\left(\sim 33^{\circ} \mathrm{C}\right.$ during the day), high solar radiation ( $\sim 90$ klux mid-day) and nutrient medium containing brine (high salt content)], will have affected the growth and biochemical composition of the $C$. vulgaris. Regarding the salinity, it is expected that $\mathrm{BBM}$ and $\mathrm{BBM}+\mathrm{DC}$ have a $\mathrm{NaCl}$ concentration of around $0.4 \mathrm{mM}$ and $10.3 \mathrm{mM} \mathrm{NaCl}$, respectively, that is, the $\mathrm{BBM}+\mathrm{DC}$ is 25 times more saline than the BBM medium. However, the salinity of BBM + DC can be considered as moderate, being much lower than that of seawater $(0.5 \mathrm{M} \mathrm{NaCl})$. Takouridis et al. (2015) demonstrated the feasible growth of the freshwater microalga Chlamydomonas reinhardtii under high salinity conditions $(0.3-0.7 \mathrm{M} \mathrm{NaCl})$ via the selective breeding method of genome shuffling. Nevertheless, only a few microalgal strains can support high salinity, for instance, Dunaliella, a green unicellular microalga isolated from high salinity water bodies with $\mathrm{NaCl}$ concentrations exceeding $3.0 \mathrm{M} \mathrm{NaCl}$ (Borowitzka and Huisman, 1993).

The fatty acids (FAs) composition of freshwater C. vulgaris after applying the proposed experimental conditions are shown in Table 6. Twelve fatty acids composed of $\mathrm{C} 12: 0$ to $\mathrm{C} 22: 6 \omega 3$ were identified. Based on their percentage of the total FA in Chlorella vulgaris, the predominant FAs were $\alpha$-linolenic acid (C18:3 ๑3 ALA, 18.5-21.0\%), palmitic acid (C16:0, 16.5-16.6\%), linoleic acid (C18:2 $\omega 6,8.7-11.2 \%)$ and oleic acid (C18:1, 7.6-11.8\%), representing $\sim 60.6 \%$ of 
total FA content. The FAs present at moderate levels were pentadecenoic acid (C15:1, 0.1-4.2\%), stearic acid $(\mathrm{C} 18: 0,0.5-3.5 \%)$ and palmitoleic acid (C16:1, $1.8-2.9 \%$ ), representing $\sim 10.6 \%$ of the total FA content. Fatty acids present at trace levels were lauric acid (C12:0, 0.3-1.2\%), myristic acid (C14:0, 0.5$1.1 \%$ ), $\gamma$-linolenic acid (C18:3 16 GLA, 0.7-1.0\%), dihomo- $\gamma$-linolenic acid (C20:3 Ф6 DGLA, 0.2-0.4\%) and docosahexaenoic acid (C22:6 $₫ 3$ DHA, 0.2-0.6\%), representing $\sim 4.4 \%$ of the total FA contents.

As shown in Table 6, C. vulgaris cells that were cultured in BBM tend to produce higher levels of PUFAs (mainly C18:2 $\omega 6$ and C18:3 $\omega 3$ ), an average of $32.2 \%$, than culture developed in BBM + DC. Furthermore, the PUFA/SFA ratio was higher for the $\mathrm{BBM}$ control (1.67) than for BBM + DC (1.21). On the other hand, C. vulgaris cultivated in BBM + DC appears to have a tendency to synthesize more SFAs (mainly C16 and C18:0), consistent with previous data on this fatty acids fraction (Matos et al., 2015). Functionally, higher synthesis of SFAs in C. vulgaris can be explained by an adaptive osmoregulatory mechanism to cope with rapid or gradual changes in salinity that are associated with algae-cell-membrane permeability (Takagi and Karseno, 2006; Lawton et al., 2015).

Table 6. Summary of fatty acid methyl esters (FAMEs) composition for $C$. vulgaris cultivated in BBM and $\mathrm{BBM}+\mathrm{DC}$.

\begin{tabular}{|c|c|c|}
\hline FAMEs (\%) & BBM & BBM + DC \\
\hline $\mathrm{C} 12: 0$ & $1.26 \pm 0.2$ & $0.34 \pm 0.1$ \\
\hline C14:0 & $0.51 \pm 0.2$ & $1.15 \pm 0.2$ \\
\hline C16:0 & $16.5 \pm 1.2$ & $16.6 \pm 1.5$ \\
\hline C18:0 & $0.54 \pm 0.1$ & $3.52 \pm 0.4$ \\
\hline Other SFA & $1.21 \pm 0.4$ & $2.25 \pm 0.8$ \\
\hline$\Sigma$ SFA & $20.2 \pm 1.5$ & $23.8 \pm 1.2$ \\
\hline C15:1 & $4.2 \pm 0.8$ & nd \\
\hline C16:1 & $1.8 \pm 0.3$ & $2.9 \pm 0.5$ \\
\hline C18:1 & $7.6 \pm 1.1$ & $11.8 \pm 1.1$ \\
\hline Other MUFA & $0.9 \pm 0.1$ & $2.3 \pm 0.3$ \\
\hline$\Sigma$ MUFA & $14.5 \pm 1.3$ & $17.0 \pm 1.3$ \\
\hline C18:3 13 (ALA) & $21.0 \pm 1.0$ & $18.5 \pm 2.3$ \\
\hline C22:6 $\omega 3$ (DHA) & $0.60 \pm 0.1$ & $0.28 \pm 0.1$ \\
\hline$\Sigma$ PUFA- $\omega 3$ & $21.6 \pm 1.3$ & $18.7 \pm 1.2$ \\
\hline C18:2 $\omega 6$ & $11.2 \pm 0.8$ & $8.7 \pm 0.6$ \\
\hline C18:3 $\omega 6$ (GLA) & $0.7 \pm 0.1$ & $1.0 \pm 0.3$ \\
\hline $\mathrm{C} 20: 3 \omega 6$ & $0.2 \pm 0.1$ & $0.4 \pm 0.1$ \\
\hline$\Sigma$ PUFA- $\omega 6$ & 12.3 & $10.1 \pm 0.4$ \\
\hline Total PUFA & $33.9 \pm 1.5$ & $28.8 \pm 1.4$ \\
\hline PUFA/SFA & 1.67 & 1.21 \\
\hline
\end{tabular}

Values shown are averages of two \pm the range. SFA (Saturated Fatty Acid), MUFA (Monounsaturated Fatty Acid), PUFA (Polyunsaturated Fatty Acid), nd (not detected).

\section{CONCLUSIONS}

This study was adapted to the community of Uruçu, located in the semiarid region of Brazil, where DC is used for many agricultural purposes. The applicability of DC as a substrate for microalgae cultivation using open raceway ponds was investigated. The microalga C. vulgaris was able to grow in $\mathrm{DC}$, but requires a maximum of $25 \%$ of DC concentration. Growth of $C$. vulgaris cells was similar in BBM and BBM + DC with a biomass productivity of an average of $7.6 \mathrm{~g} \mathrm{~m}^{-2}$ day $^{-1}$. Cultures developed in BBM showed a protein content of $37.2 \%$ while in BBM + DC the same metabolite was $20.0 \%$, indicating that $C$. vulgaris cultivated in DC shifts its metabolism to osmoregulation rather than towards the synthesis of proteins. Finally, this study demonstrated the use of available DC as nutrient feedstock, which could reduce the need for fresh water and external nutrients. This can be considered as a step forward for the valorization of brine management through algal mass cultivation.

\section{ACKNOWLEDGMENTS}

This work was supported by the Brazilian Government through the Conselho Nacional de Desenvolvimento Científico e Tecnológico - CNPq (Project number 574.716/2008-4). A.P. Matos is grateful to CAPES for a scholarship. We also acknowledge the chemical analyses provided by the Laboratory of Analysis (LABCAL/UFSC) for this research.

\section{REFERENCES}

ANVISA, Agência Nacional de Vigilância Sanitária. Aprova Regulamento Técnico sobre Rotulagem Nutricional de Alimentos Embalados, tornando obrigatória a rotulagem nutricional. Resolução $n^{\circ}$ 360, Brazil (2003)

AOAC, AOAC Official Method 963.15, 991.20. In: Official Methods of Analysis of AOAC International, 18th ed. AOAC International, Gaithersburg (2005).

APHA, American Public Health Association. Standard Methods for the Examination of Water and Wastewater, 21st ed., Washington, DC (2005).

Ashokkumar, V., Agila, E., Salam, Z., Ponraj, M., Din, M. F. M., Ani, F. N., A study on large scale cultivation of Microcystis aeruginosa under open raceway pond at semi-continuous mode for biodiesel production. Bioresource Technology, 172, 186-193 (2014).

Batista, A.P., Gouveia, L., Bandarra, N.M., Franco, J.M., Raymundo, A., Comparison of microalgal biomass profiles as novel functional ingredient for food products. Algal Research, 2, 164-173 (2013).

Bhowmick, G. D., Subramanian, G., Mishra, S., Sen, R., Raceway pond cultivation of a marine microalga of Indian origin for biomass and lipid production: A case study. Algal Research, 6, 201-209 (2014). 
Borges, J. A., Rosa, G. M., Meza, L. H. R., Henrard, A. A., Souza, M. R. A. Z., Costa, J. A. V., Spirulina sp. LEB-18 culture using effluent from the anaerobic digestion. Brazilian Journal of Chemical Engineering, 30, 277-287 (2013).

Borowitzka, M. A., Huisman, J. M., The ecology of Dunaliella salina (chlorophyceae, volvocales): Effect of environmental conditions on aplanospore formation. Botanica Marina, 36, 233-244 (1993).

Cheng, J., Yang, Z., Huang, Y., Huang, L., Hu, L., Xu, D., Zhou, J., Cen, K., Improving growth rate of microalgae in a $1192 \mathrm{~m}^{2}$ raceway pond to fix $\mathrm{CO}_{2}$ from flue gas in a coal-fire power plant. Bioresource Technology, 190, 235-241 (2015).

Chu, H. Q., Tan, X. B., Zhang, Y. L., Yang, L. B., Zhao, F. C., Guo, J. Continuous cultivation of Chlorella pyrenoidosa using anaerobic digested starch processing wastewater in the outdoors. Bioresource Technology, 185, 40-48 (2015).

Craggs, R. J., Sutherland, D., Campbell, H., Hectarescale demonstration of high rate algal ponds for enhanced wastewater treatment and biofuel production. Journal of Applied Phycology, 24, 329337 (2012).

Cuello, M. C., Cosgrove, J. J., Randhir, A., Vadiveloo, A., Moheimani, N. R., Comparison of continuous and day time only mixing on Tetraselmis suecica (Chlorophyta) in outdoor raceway ponds. Journal of Applied Phycology, 27, 1783-1791 (2015).

El-Sheekh, M., Abomahra, E. F. A., Hanelt, D., Optimization of biomass and fatty acid productivity of Scenedesmus obliquus as a promising microalga for biodiesel production. World Journal of Microbiology and Biotechnology, 29, 915-922 (2013).

Eustance, E., Badvipour, S., Wray, J. T., Sommerfield, M. R., Biomass productivity of two Scenedesmus strains cultivated semi-continuously in outdoor raceway ponds and flat-panel photobioreactor. Journal of Applied Phycology, 28, 1471-1483, (2016).

Graham, L. E., Graham, J. M., Wilcox, L. W., Algae, second ed. Benjamin Cummings, Pearson. 720p (2008).

Greenlee, L. F., Lawler, D. F., Freeman, B. D., Marrot, B., Moulin, P., Reverse osmosis desalination: Water sources, technology, and today's challenges. Water Research, 43, 2317-2348 (2009).

Grobbelaar, J. U., From laboratory to commercial production: a case of study of a Spirulina (Arthrospira) facility in Musina, South Africa. Journal of Applied Phycology, 21, 523-527 (2009).

Halim, R., Danquah, M. K., Webley, P. A., Extraction of oil from microalgae for biodiesel production: A review. Biotechnology Advances, 30, 709-732 (2012).
Huo, S., Wang, Z., Zhu, S., Zhou, W., Dong, R., Yuan, Z., Cultivation of Chlorella zofingiensis in benchscale outdoor ponds by regulation of $\mathrm{pH}$ using dairy wastewater in winter, South China. Bioresource Technology, 121, 76-82 (2012).

IAL, Instituto Adolfo Lutz. Normas Analíticas do Instituto Adolfo Lutz. Métodos químicos e físicos para análise de alimentos. $3^{\text {rd }}$ ed. São Paulo: IMESP (2005).

Kumar, K., Mishara, S. K., Shrivastav, A., Park, M. S., Yang, J. W., Recent trends in the mass cultivation of algae in raceway ponds. Renewable \& Sustainable Energy Reviews, 51, 875-885 (2015).

Lawton, R. J., Nys, R., Magnusson, M. E., Paul, N. A., The effect of salinity on the biomass productivity, protein and lipid composition of a freshwater macroalga. Algal Research, 12, 213-220 (2015).

Lattemann, S., Hopner, T., Environmental impact and impact assessment of seawater desalination. Desalination, 220, 1-15 (2008).

Ledda, C., Romero-Villegas, G. I., Adani, F., AciénFernández, F. G., Molina-Grima, E., Utilization of centrate of wastewater treatment for the outdoor production of Nannochlorospsis gaditana biomass at pilot-scale. Algal Research, 12, 17-25 (2015).

Lee, O. K., Oh, Y. K., Lee, E. Y., Bioethanol production from carbohydrate-enriched residual biomass obtained after lipid extraction of Chlorella sp. KR1. Bioresource Technology, 196, 22-27 (2015).

Lourenço, S. O., Barbarino, E., Lavín, P. L., Marquez, U. M. L., Aidar, E., Distribution of intracellular nitrogen in marine microalgae: calculation of new nitrogen-to-protein conversion factors. European Journal of Phycology, 39, 17-32 (2004).

Lourenço, S. O., Isolamento de microalgas, purificação e medidas de crescimento. In: Lourenço SO (eds) Cultivo de microalgas marinhas: Princípios e aplicações. São Carlos: RiMa, pp 221-294 (2006).

Lu, W., Wang, Z., Yuan, Z., Characteristics of lipid extraction from Chlorella sp. cultivated in outdoor raceway ponds with mixture of ethyl acetate and ethanol for biodiesel production. Bioresource Technology, 191, 433-437 (2015).

Matos, A. P., Ferreira, W. B., Torres, R. O. C., Morioka, L. R. I., Canella, M. H. M., Rotta, J., Silva, T., Moecke, E. E. S., Sant'Anna, E. S., Optimization of biomass production of Chlorella vulgaris grown in desalination concentrate. Journal of Applied Phycology, 27, 1473-1483 (2015).

Matos, A. P., Moecke, E. E. S., Sant'Anna, E. S., The use of desalination concentrate as a potential substrate for microalgae cultivation in Brazil. Algal Research, 24, 505-508 (2017).

Megazyme dietary fiber analysis, based on AACC (Method 32-05-01) and AOAC (Official Method 985.29). Megazyme International Ireland Ltd, Wicklow, Ireland (2017). 
Melián-Martel, N., Sadhwani, J. J., Báez, S. O. P., Saline waste disposal reuse for desalination plants for the chlor-alkali industry: The particular case of Pozo Izquierdo SWRO desalination plants. Desalination, 281, 35-41 (2011).

MMA - Ministério do Meio Ambiente, Secretaria de Recursos Hídricos eAmbiente Urbano, Programa Água Doce, http://www.mma.gov.br/agua/aguadoce2004.

Moheimani, N. R., Parlevliet, D., McHenry, M. P., Bahri, P. A., Boer, K., Past, present and future of microalgae cultivation developments. In: Moheimani, N. R., McHenry, M. P., Boer, K., Bahri, P. A., Biomass and biofuels from microalgae: advances in engineering and biology, Springer International Publishing, Switzerland, pp. 1-18 (2015).

Morales-Amaral, M. M., Gómez-Serrano, C., Acién, F. G., Fernández-Sevilha, J. M., Molina-Grima, E., Outdoor production of Scenedesmus sp. in thinlayer and raceway reactors using centrate from anaerobic digestion as the sole nutrient source. Algal Research, 12, 99-108 (2015).

Morioka, L. R. I., Matos, A. P., Olivo, G., Sant'Anna, E. S., Floculação de Chlorella sp. produzida em concentrado de dessalinização e estudo de método de extração de lipídeos intracelulares. Química Nova, 37, 44-49 (2014).

Nichols, H. W., Growth media-freshwater. In: Stein, J. (Ed.), Handbook of Phycological Methods: Culture Methods and Growth Measurements. Cambridge University Press, Cambridge, pp 7-24 (1973).

Olguín, E. J., Galicia, S., Mercado, G., Pérez, T., Annual productivity of Spirulina (Arthrospira) and nutrient removal in a pig wastewater recycling process under tropical condition. Journal of Applied Phycology, 15, 249-257 (2003).

Olaizola, M., Commercial production of astaxanthin from Haematococcus pluvialis using 25,000-liter outdoor photobioreactors. Journal of Applied Phycology, 12, 499-506 (2000).

Park, J. B. K., Craggs, R. J., Shilton, A. N., Wastewater treatment high rate algal ponds for biofuel production. Bioresource Technology, 102, 35-42 (2011).

Pittman, J. K., Dean, A. P., Osudenko, O., The potential of sustainable algal biofuel production using wastewater resources. Bioresource Technology, 102, 17-25 (2011).

Raes, E. J., Isdepsky, A., Muylaert, K., Borowitzka, M. A., Moheimani, N. R., Comparison of growth of Tetraselmis in a tubular photobioreactor (Biocoil) and a raceway pond. Journal of Applied Phycology, 26, 247-255 (2014).
Ritchie, R. J., Consistent sets of spectrophotometric chlorophyll equations for acetone, methanol and ethanol solvents. Photosynthesis Research, 89, 2741 (2006).

Sánchez, A. S., Nogueira, I. B. R., Kalid, R. A., Uses of the reject brine from inland desalination for fish farming, Spirulina cultivation, and irrigation of forage shrub and crops. Desalination, 364, 96-107 (2015).

Sing, S. F., Isdepsky, A., Borowitzka, M. A., Lewis, D. M., Pilot-scale continuous recycling of growth medium for the mass culture of a halotolerant Tetraselmis sp. in raceway ponds under increasing salinity: A novel protocol for commercial microalgal biomass production. Bioresource Technology, 161, 47-54 (2014).

Skorupskaite, V., Makareviciene, V., Levisaukas, D., Optimization of mixotrophic cultivation of microalgae Chlorella sp. for biofuel production using response surface methodology. Algal Research, 7, 45-50 (2015).

Takagi, M., Karseno, Y. T., Effect of salt concentration on intracellular accumulation of lipids and triacylgliceride in marine microalgae Dunaliella cells. Journal of Bioscience and Bioengineering, 101, 223-226 (2006).

Takouridis, S. J., Tribe, D. E., Gras, S. L., Martin, G. J. O., The selective breeding of the freshwater microalga Chlamydomonas reinhardtii for growth in salinity. Bioresource Technology, 184, 18-22 (2015).

Tibbetts, S. M., Whitney, C. G., MacPherson, M. J., Bhatti, S., Banskota, A. H., Stefanova, R., McGinn, P. J., Biochemical characterization of microalgal biomass from freshwater species isolated in Alberta, Canada for animal feed applications. Algal Research, 11, 435-447 (2015).

Tran, K. C., Mendoza-Martin, J. L., Heaven, S., Banks, C. J., Acien-Fernandez, F. G., MolinaGrima, E., Cultivation and anaerobic digestion of Scenedesmus spp. grown in a pilot-scale open raceway. Algal Research, 5, 95-102 (2014).

Varshney, P., Mikulic, P., Vonshak, A., Beardall, J., Wangikar, P. P., Extremophilic micro-algae and their potential contribution in biotechnology. Bioresource Technology, 184, 363-372 (2015).

Wu, Z. Y., Shi, C. L., Shi, X. M., Modeling of lutein production by heterotrophic Chlorella in batch and fed-batch cultures. World Journal of Microbiology and Biotechnology, 23, 1233-1238 (2007). 